\title{
Cystatin C and cardiovascular risk in HIV infected patients
}

\author{
Katia Falasca, Claudio Ucciferri, Paola Mancino, Francesca Vignale, Jacopo Vecchiet \\ From $16^{\text {th }}$ International Symposium on HIV and Emerging Infectious Diseases \\ Marseille, France. 24-26 March 2010
}

\section{Background}

HIV infection, combined antiretroviral therapy (cART) and metabolic syndrome are associated to an increased cardiovascular risk (CVR). Cystatin C, a low molecular weight cysteine protease inhibitor involved in vascular extracellular matrix remodelling, is considered a novel marker of kidney function and CVR in general population. To value the role of cystatin C in HIV infected patients without chronic kidney disease treated with cART subdivided for CVR.

\section{Methods}

56 Caucasian HIV+ cART treated patients without chronic kidney disease were subdivided by means of Framingham score into two groups: A) 15 patients with "high" CVR, and B) 41 patients with "low" CVR. Viroimmunological parameters, triglycerides (TGs), total cholesterol (TCh), HDL (HDL-C) and LDL (LDL-C) cholesterol, blood pressure, microalbuminuria, GFRMDRD, fasting glucose, insulinemia, HOMA-IR, CRP, cystatin C, IL-18, IL-6, body mass index (BMI) and waist-to-hip ratio (WHR) were measured.

\section{Results}

The two groups were homogeneous for years of cART, CD4- and CD8- T cell count, viral load. Group A showed statistically higher levels of BMI $(\mathrm{p}<0.009)$, WHR $(\mathrm{p}<0.001)$, TCh $(\mathrm{p}<0.001)$, LDL-C $(\mathrm{p}<0.001)$, TGs $(\mathrm{p}<0.02)$, systolic blood pressure $(\mathrm{p}<0.001)$, fasting glucose $(\mathrm{p}<0.002)$, insulinemia $(\mathrm{p}<0.008)$, HOMA-IR $(\mathrm{p}<0.001)$, cystatin $\mathrm{C}(\mathrm{p}<0.001)$, microalbuminuria ( $\mathrm{p}<0.001)$, IL-6 $(\mathrm{p}<0.03)$ and IL-18 ( $<$ 0.01 ). The GFR-MDRD and the inflammatory index CRP did not show significant differences between the

\footnotetext{
* Correspondence: ucciferri@tiscali.it

Infectious Disease Clinic, Department of Medicine and Science of Aging, G. d'Annunzio University, Chieti, Italy
}

two groups. Finally, data showed a positive correlation between CVR and cystatin $C(r=0.39$ and $p=0.003)$.

\section{Discussion}

In the present study it is remarkable that patients in "high" CVR group showed higher values of cystatin $\mathrm{C}$ and microalbuminuria even though kidney function was normal. Also microalbuminuria, besides its relation with progressive renal damage, has been found to be an independent factor of CVR and mortality in the general population. Furthermore, the positive correlation between CVR and cystatin $\mathrm{C}$ found in this study for the first time in HIV positive patients, is in accord with the evidence existing in literature of a strong association between cystatin $C$ and CVR in the general population. These findings may indicate that cystatin $C$ and microalbuminuria could serve as early markers of enhanced CVR, besides of renal complications, in the HIV-infected population.

Published: 11 May 2010

doi:10.1186/1742-4690-7-S1-P62

Cite this article as: Falasca et al:: Cystatin $\mathrm{C}$ and cardiovascular risk in HIV infected patients. Retrovirology 2010 7(Suppl 1):P62.

Submit your next manuscript to BioMed Central and take full advantage of:

- Convenient online submission

- Thorough peer review

- No space constraints or color figure charges

- Immediate publication on acceptance

- Inclusion in PubMed, CAS, Scopus and Google Scholar

- Research which is freely available for redistribution

Submit your manuscript at www.biomedcentral.com/submit
Biomed Central 